\title{
Effect of coconut oil in the post-weaning starter diet on growth and carcass qualities of male lambs, weaned early and intensively fattened in winter
}

\author{
G Bozzolo 1, M Bouillier-Oudot 1, M Candau 1 \\ with the technical assistance of G El Hasbani 1, D Grasset 2, H Manse 1 \\ ${ }^{1}$ École Nationale Supérieure Agronomique, 31076 Toulouse Cedex; \\ ${ }^{2}$ Groupement des Éleveurs de Brebis du bassin de Roquefort, 12001 Millau Cedex, France
}

(Received 18 November 1992; accepted 16 February 1993)

\begin{abstract}
Summary - The influence of medium-chain fatty acids (5\% coconut oil) introduced in a starter diet (ALC) for $21 \mathrm{~d}$ after weaning was investigated in 230 Lacaune male lambs. They were weaned early, intensively fattened during winter and slaughtered at a constant live-weight $(39 \mathrm{~kg})$. Comparisons have been made regarding the individual growth rates and carcass qualities with an isocaloric and isonitrogenous reference diet (ALr) from lamb sub-samples. During the period of actual starter diet utilization, ALc induced a higher growth rate $(+59 \%)$ independently of the weaning weight (Wto). The feed conversion ratio was lower with ALc $(P<0.01)$. The induced weight difference remained after the lambs were fed on the same finishing diet. The growth pattern for the entire fattening period was more regular with ALc, particularly when lamb weight was medium (12 kg) of light (Wto $<11 \mathrm{~kg}$ ) at weaning. The volatile fatty acid pattern in the rumen fluid over time (sampling with a rumen vacuum pump) and throughout the transition between starter and fattening diets (Rusitec procedure) did not show a clear coconut oil effect. ALc induced a slight increase in the external fat layer at slaughter 2 months later, especially in heavy lambs. Firmness and colour of subcutaneous fatty tissue were not different, but ALc tended to result in firmer and whiter carcasses in the case of the heavier lambs at weaning.
\end{abstract}

coconut oil / male lamb / growth / carcass

Résumé - Effet de l'incorporation d'huile de coprah dans l'aliment de post-sevrage sur la croissance et les qualités de carcasse d'agneaux mâles, sevrés précocement et engraissés intensivement durant l'hiver. L'influence des acides gras à chaîne carbonée de moyenne longueur (5\% d'huile de coprah) introduits dans l'aliment starter (ALC) est examinée à partir de 230 agneaux mâles Lacaune. Sevrés précocement et engraissés intensivement l'hiver, ils furent abattus à poids constant $(39 \mathrm{~kg})$. Les performances de croissance individuelle et les qualités de carcasse sont comparées à celles d'un régime témoin (ALr) isoénergétique et iso-azoté. Pendant la phase de croissance soumise à linfluence directe de l'aliment starter (0-20 j). ALc induit une plus forte vitesse de croissance $(+59 \%)$ indépendamment du poids au sevrage (Wto). Sur l'ensemble de l'engraissement, ALc induit de manière rémanente l'augmentation de la vitesse de croissance. L'évolution de la 
courbe de croissance est plus régulière avec ALC, particulièrement quand les agneaux sont d'un poids moyen $(12 \mathrm{~kg}$ ) ou léger (Wto $<11 \mathrm{~kg}$ ). Durant la période de démarrage, l'indice de consommation est plus faible avec ALC. L'évolution des profils d'acides gras volatils dans le rumen et en fermenteur (Rusitec) durant la transition entre les régimes de démarrage et d'engraissement ne montre pas d'effet de l'huile de coprah. ALc produit un léger accroissement du recouvrement du gras externe, deux mois plus tard, surtout chez les agneaux lourds au départ. Dans l'ensemble, fermeté et couleur du tissu gras sous-cutané ne diffèrent pas. Cependant, les agneaux lourds au sevrage tendent à présenter des carcasses plus fermes et plus blanches.

huile de coprah / agneau mâle / croissance / carcasse

\section{INTRODUCTION}

The production of male lambs intensively fed indoors on concentrates causes several problems. Feeding large amounts of high starch diet to lambs results in a high rate of propionic fermentation in the rumen. This trend produces inadequate carcasses which often exhibit coloured oily subcutaneous fats (Garton et al, 1972; Molénat and Thériez, 1973; Ørskov et al, 1975; Busboom et al, 1981). In another connection, compensatory growth adjustments take place when lambs are able to govern their own apetite (Andrews and Ørskov, 1970; Ferrell et al, 1986; Turgeon et al, 1986). The regularity of the growth curve consequently depends on growth rate in the post-weaning stage as lambs enter the feed-lot. Water retention in tissues and intensive protein anabolism (Ferrell et al, 1986) could result if this adjustment occurs later in the finishing stage, ie when lambs have reached up 30\% of their live weight at maturity and when lipid deposition is normally increasing. These 2 events could conflict with building up good quality fat deposits.

Therefore growth rate always depends on the starter diet provided during the transitory post-weaning stage if markedly depressed growth appears at the outset of this stage, compensatory growth could take place later. This starter diet must pro- vide medicinal protection for stressed lambs and offer an easily convertible energy substrate. This is necessary since these lambs are temporarily confronted with a deficient energy intake. In most cases, it leads to delayed growth or even to weight loss (Bénévent, 1971; Lane and Albrecht, 1991). In this instance, the starter diet must also compensate the lack of efficiency of the enzymatic gut system, which at this stage is still underdeveloped, particularly as regards starch digestion (Leat and Harrison, 1975). During this stage, the use of dietary medium chain fatty acids to supply energy demand showed a high level of efficiency with monogastric animals (Frost and Wells, 1981; Benevenga et al, 1989; Cera et al, 1989 for piglets; Jensen et al, 1986, for infants). Regarding preruminant lambs, Aurousseau et al (1973) have suggested that the introduction of coconut oil in a milk-replacer diet has a direct effect on growth rate. They also noticed a remaining effect on fatness qualities in these lambs if the latter were weaned and fattened indoors. Sutton et al (1983) reported a reduction of the butyric, isobutyric and isovaleric acid contents in the ruminal fluid induced by coconut oil fatty acids. It is known that these volatile fatty acids are inductors of odd and branched subcutaneous fatty acids (Garton et al, 1972). In coconut oil, lauric acid is well distributed. In addition, with its immediate hepatic energy use, it can be transformed into myristic and 
palmitic acids by elongation of the carbon chain (Christie, 1981). It could then improve fat hardness as palmitic acid is poorly sensitive to fat cells desaturase activity (Wahle, 1974). Bozzolo et al (1991) observed a marked effect on early weaned male lambs reared during summer following the incorporation of coconut oil in the starter diet. The difference was more than $+233 \%$ for average daily gain in the light category of lambs at weaning $(W t<11 \mathrm{~kg})$ and the carcasses were whiter. By assuming a seasonal effect (hot weather) it was necessary to confirm these results with winter fed indoor lambs which are the major product of the Roquefort area in France.

\section{MATERIAL AND METHODS}

\section{Animals and management}

Two equilibrated lots of Dairy Lacaune male lambs (230) were used in this experiment. They were weaned early $(<35 d)$ and then fattened indoors in the same sheep fold (GEBRO Rear- ing Center), during winter and early spring (January-March).

Two starter diets were compared. They consisted of complete pelleted concentrated diets $(\varnothing=4 \mathrm{~mm} ; \mathrm{L} \approx \pm 12 \mathrm{~mm})$ and were fed ad libit$u m$. The lambs received the former diets for 21 d $\approx 12 \mathrm{~kg} / \mathrm{lamb})$; straw complement was also freely accessible. The first (ALr) was a commercial diet and was used as a reference. The secand (ALC) was supplied with $5 \%$ coconut oil (table 1). Both diets were formulated to provided isocaloric and isonitrogenous values. Afterwards, the same fattening finishing diet was provided to both lots. Foodstuff characteristics and chemical composition (table II), were determined according to JOCE procedures (1971, 1972,1973 ). The estimated energy value (Giger-Reverdin et al, 1990) were close for both diets $(\mathrm{ME}=11.38 \mathrm{MJ} / \mathrm{kg} \mathrm{DM}$ vs $11.70 \mathrm{MJ}$ in ALC), as were the proportions of crude protein $(18 \%)$. The total fat percentage was 2-fold higher in ALc (6\% vs 3\% in ALr). Coconut oil constituted $78 \%$ of the total fat in ALc. In the reference diet, the percentage of animal fat $10.8 \%$ bone fat in the formula) was $26 \%$. Fatty acid composition was determined by gas chromatography after lipid extraction by the Folch procedure (Folch et al, 1957) and methyl ester preparation according to the AFNOR method (NFT 60-233). In ALc, the proportion of saturated fatty acids (FA) was higher than in $\operatorname{ALr}(58 \%$ vs $29 \%$ ). On a dry matter basis, ALC had $3.4 \%$ saturated FA and $2.4 \%$

Table I. Ingredient compositon of starter diets fed to lambs.

Constituents ( $\mathrm{g} / \mathrm{kg}$ fresh diet)

ALr (reference)

ALc (coconut oil)

Ground cereals

Brewers' grains

Citrus pulp

Dehydrated alfalfa meal

Ground peas

Soybean extracted meal

Sunflower extracted meal

Liquid molasses

Bone fat

Coconut oil

Mineral mix

Additive $(Z 88+Z 20)$

Vitamin mix (Z15)

$\begin{array}{rr}518 & 281 \\ 14 & 17 \\ 50 & 51 \\ 56 & 200 \\ 100 & 100 \\ 142 & 118 \\ 11 & 80 \\ 50 & 50 \\ 6 & - \\ - & 50 \\ 41 & 41 \\ 9 & 9 \\ 3 & 3\end{array}$

281

17

51

200

100

18

80

50

50

41

3 
Table II. Chemical composition and energy value of the experimental diets.

Composition of the diets

Constituents $(\mathrm{g} / \mathrm{kg})$

Starter diets

ALr (reference) ALC (coconut) Fattening diet

Dry matter (DM)
Dry matter content $(\mathrm{g} / \mathrm{kg})$
Ash
Acid detergent fiber
Lignin
Crude protein
Ether extract
ME (MJ/kg DM) a

$\begin{array}{ccc}902 & 904 & 905 \\ 90 & 91 & 82 \\ 96 & 121 & 109 \\ 29 & 33 & 30 \\ 176 & 181 & 165 \\ 28 & 58 & 32 \\ 11.38 & 11.70 & 11.51\end{array}$

Composition of the dietary lipids ( $g / 100 \mathrm{~g}$ total methylic esters)

\begin{tabular}{|c|c|c|c|}
\hline $\mathrm{C}_{10}$ & $\operatorname{tr} b$ & 2.6 & $\operatorname{tr}$ \\
\hline C12 & $\operatorname{tr}$ & 24.7 & 0.4 \\
\hline C14 & 1.2 & 9.1 & 1.8 \\
\hline$C_{14}=1$ & 0.3 & 0.2 & $\operatorname{tr}$ \\
\hline C15 & 0.4 & 0.2 & 0.3 \\
\hline $\mathrm{C} 16$ & 20.2 & 15.4 & 21.1 \\
\hline $\mathrm{C} 16=1$ & 1.6 & 0.9 & 1.7 \\
\hline Antiso $\mathrm{C} 17$ & 0.5 & 0.3 & 0.4 \\
\hline $\mathrm{C} 17$ & 1.1 & 0.7 & 0.8 \\
\hline$C 17=1$ & 1.1 & 0.5 & 0.6 \\
\hline C18 & 5.6 & 4.8 & 7.3 \\
\hline$C_{18}=1$ & 27.8 & 18.5 & 30.1 \\
\hline $\mathrm{C} 18=2$ & 35.2 & 18.9 & 31.4 \\
\hline $\mathrm{C} 18=3$ & 4.9 & 2.7 & 3.7 \\
\hline $\mathrm{C} 20=1$ & 0.3 & 0.2 & 0.2 \\
\hline$\Sigma$ Saturated FA & 28.8 & 58.3 & 32.1 \\
\hline$\Sigma$ Unsaturated FA & 71.2 & 41.7 & 67.8 \\
\hline$\Sigma F A<C 15$ & 1.8 & 37.3 & 2.5 \\
\hline
\end{tabular}

a ME estimated by the Giger-Reverdin predictive equation $(1990) ;{ }^{b}$ tr: trace level $<0.01 \mathrm{~g}$.

unsaturated FA vs $0.8 \%$ and $2 \%$ in ALr. Of the medium fatty acids, ALc possessed a higher proportion than ALr (FA $<\mathrm{C}_{15}=2.2 \%$ DM vs $0.5 \%$ ). In particular, the lauric acid level (present in coconut oil) constituted $25 \%$ of total FA in ALC. ALr was more highly supplied with $\mathrm{C}_{18=2}$ than ALc (35\% vs $19 \%$ of total FA). This was due to cereal and bone constituents.

The lambs were then fed until slaughter with the growing-fattening diet gradually introduced (for $5 \mathrm{~d}$ ). The slaughtering decision took place after a weekly sorting, when the live-weight of lambs reached $>39 \mathrm{~kg}$.

\section{Measured parameters}

Three groups of observations were made: a) rearing and growing characteristics; b) develop- 
ment of the microbial activity in the rumen reflected by VFA production; and c) carcass characteristics.

The first group included:

- Initial parameters: weight and age at start of fattening $\left(A g_{0} ; W t_{0}\right)$ and the littermate at birth $(B I)$. These indicate lamb status before experimentation.

- Average daily gains ( $A D G$ ) during the various growth stages $\left(A D G_{0-20 \mathrm{~d}}, A D G_{20-40 \mathrm{~d}}, A D G_{40-60 \mathrm{~d}}\right.$, $\left.A D G_{60-S 1}, A D G_{0-S i}, A D G_{20-S 1}\right)$ were computed from individual lamb weight at $0,20,40$ and 60 $\mathrm{d}$ of fattening, and at slaughter ( $\mathrm{S})$.

- The total duration of fattening (Dufat) was reported.

- Feed conversion ratio ( $F C R=\mathrm{kg}$ ingested $\mathrm{DM} /$ $\mathrm{kg}$ gain) were sequentially computed from the amounts of food daily ingested in each lot. An average ratio was calculated from the equation $F C R m=Q d m / A D G m(Q d m=$ average weight of $\mathrm{DM}$ eaten/day/lamb). Standard mean error (SE) was estimated from the allometric identity between food ingested and animal live-weight according to the relation (Bozzolo et al, 1992):

$S E_{(F C R)}=F C R m(b-1)\left[\left(S d_{P i}\right)^{2}+S d_{P(i+1)^{2}}+\right.$ $\left.2 r S d_{P i} S d_{P(i+1)}\right]^{0.5}\left(P_{i}+P_{(i+1)}\right)^{-1}$ with $P i$ and $P(i+1)$ being 2 successive live-weights, $r$ the correlation coefficient between them, and $b$ the allometric coefficient throughout the entire period of fattening.

The second group was investigated by sampling rumen fluid randomly taken from 6 lambs in each group via a stomach vacuum pump at $20,50 \mathrm{~d}$ of fattening and at slaughter. Analysis of the volatile fatty acid content (VFA\% in mol) was performed by gas chromatography according to Jouany's procedure (1982) for each sample. Concurrently, for each diet 2 semicontinuous incubators (Rusitect) (Czerkawski and Brekenridge, 1977) were inoculated with rumen fluid to follow the volatile fatty acid pattern during the transition stage between the 2 successive starter and fattening diets (at $20 \mathrm{~d}$ fattening). Nylon bags were introduced every $24 \mathrm{~h}$ and incubated for $48 \mathrm{~h}$ according to the procedure of Blanchart et al (1989). Starter and fattening diets were provided with $12 \%$ straw complement (average consumption of lambs issued from former controls) and monitored for $11 \mathrm{~d}$ and $7 \mathrm{~d}$ respectively.

The third group reports the observations made on chilled carcasses $\left(4^{\circ} \mathrm{C}\right) 18 \mathrm{~h}$ after slaughter. The main parameters were: carcass weight (Wcar), kill-out percentage (KO\%), conformation and external fat scores (Nconf, NFext) according to the EUROPA criteria. In more detail, fat levels were investigated by measuring the depth of dorsal fat (NFdo in $\mathrm{mm}$ ) between and beside the first and the second lumbar vertebrae. Internal fat was estimated by the perinephric fat weight (NFro in g) and inter-rib fat development (Nfir) with a 5-step scale. Fat layer qualities were estimated with a 4-level firmness scale (NFirm $1=$ soft and oily fat; $4=$ very firm fat) according to Bouillier-Oudot et al (1992) and with 7 colouring levels ( $N$ coul 1 = white; $7=$ light bistre with greenish reflection) by comparison to the Munsell toner (Bozzolo et al, 1990). The same operator performed all the measurements at the slaughterhouse.

\section{Statistics}

From a preliminary analysis of data, $W_{0}$ appeared to be correlated with the post-20-d variables. As intra-group linear responses were not parallel, the covariance analysis procedure was not adopted. Moreover, some losses of identification (tip-tags) and mortality changed the initial allocation. Subsamples of lambs were therefore taken. These were evenly distributed around the mean, with equilibrated class frequencies in both diets and in respect of the normal distribution, as follows (fig 1):

- One standardized sample for each treatment was initially composed of an identical number of randomly selected lambs in every $\mathrm{kg}$ division on both sides of the average $W t_{0}(12 \mathrm{~kg})$. This distribution resulted in 62 lambs in each diet group.

- Two marginal samples for each treatment were composed of lambs (17 lambs per group) with opposite weight characteristics at the start (heavy $>13 \mathrm{~kg}$; light $<11 \mathrm{~kg}$ ) in order to investigate the weight $\left(W_{t_{0}}\right) \times$ diet cross-effect and the main live-weight effect. The frequency classes were equilibrated in each $500-\mathrm{g}$ division from the lower and the upper limits.

Comparisons were carried out with Student's $t$-test for the first standardized sample. The second sample was investigated by factorial variance analysis $(2 \times 2$ [diets $\times$ weights], with cross-effect and 17 replicates); each parameter was treated independently. 

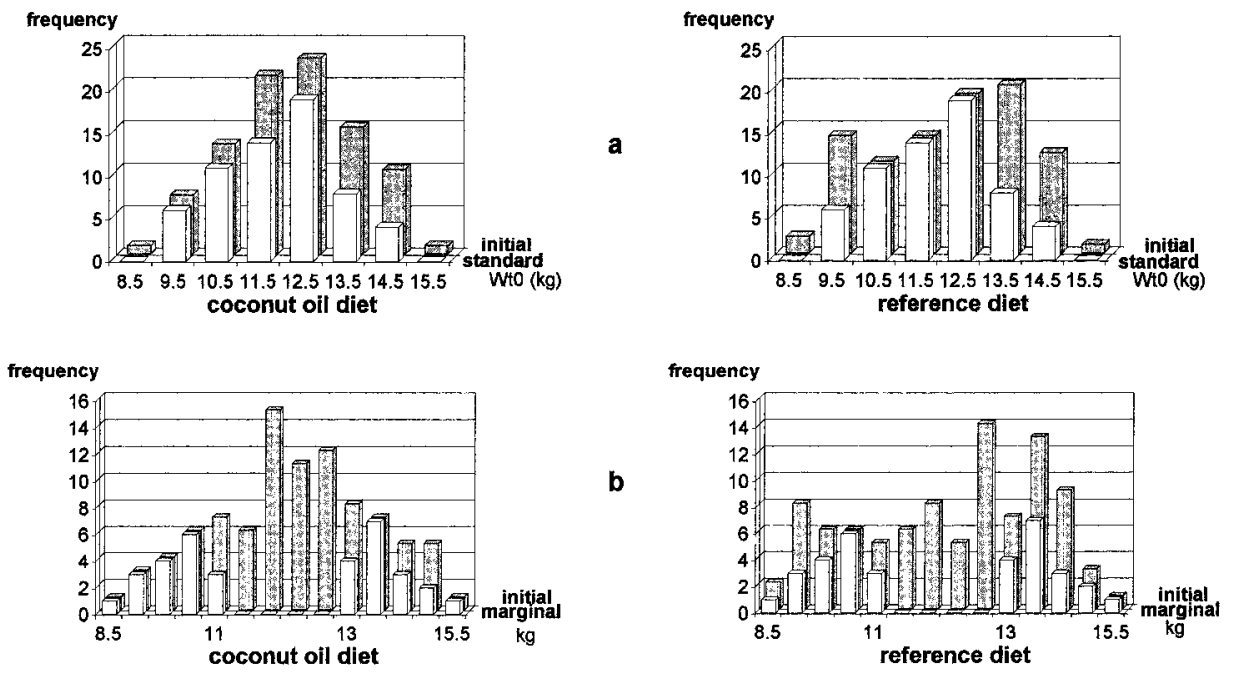

Fig 1. Frequency histograms. a. Standardized samples of lambs according to the weaning weight (average $W t_{0}=12 \mathrm{~kg} ; n=62$ ) for both diets (reference, coconut) and to the equilibrated a) $1 \mathrm{~kg}$, divisions around the average; b) samples of marginal lambs (light $<11 \mathrm{~kg}$ heavy $>13 \mathrm{~kg} ; n=17$ ) with equilibrated 500-g divisions.

As the rates of growth within time were autocorrelated and as the matrix of variance and covariance was not spherical, the growth tendencies were examined by individual polynomial regression fitted on time. The resulting coefficients were subjected to variance analysis (Allen et al, 1983).

Feed conversion ratios were tested with Student's $t$-test from the standard error estimated on the whole lot.

The patterns of relative frequencies from qualitative or ordinal data (NFirm, Ncoul, Bi) were compared by the $\chi^{2}$ procedure. When patterns were significantly different, each frequency was compared according to the diets by the standardized normal variable procedure with Yate's correction for continuity.

\section{RESULTS}

\section{Growth parameters}

\section{Standardized samples $(2 \times[n=62])$}

Table III shows only a very significant difference on $A D G$ between 0 and $20 \mathrm{~d}$. It was higher in ALc than in the reference diet when lambs were fed on starter diet ( $+63 \% ; P<0.0001)$. During other stages, growth rates did not differ from the reference. Within the entire fattening period $(0 \mathrm{~d}-\mathrm{SI})$, the coconut diet tended to induce better growth $(+4 \% ; P<0.09)$ and thus to reduce duration of fattening $(-4 \mathrm{~d} ; P<$ 0.11 ). Consequently, the pattern of the growth curve in ALC was more regular (fig 2 ; table IV). Each of the polynomial adjustment coefficients was different $(P<0.05)$ between diets and notably the first $2\left(a_{0}\right.$ and $a_{1}$ ) which influence the beginning of the growth curve. The maximum growth rate and corresponding average fattening duration did not differ between the 2 diets $\left(A D G_{\max }=406 \mathrm{mg} ; D_{\max }=70 \mathrm{~d}\right)$.

\section{Samples of marginal lambs (heavy and light; $4 \times[n=17])$}

The effect of the coconut oil was clearly pronounced throughout the first stage $(0-$ $20 \mathrm{~d})$. It induced a mean relative increase of $+59 \%$ on growth rate (178 g vs $112 \mathrm{~g}$; 
Table III. Standardized samples: influence of diets on growth and carcass parameters.

Initial husbandry characteristics of both the compared lots

$\begin{aligned} & \text { Reference } \\ & \operatorname{diet}(A L r)\end{aligned} \quad S E \quad \begin{gathered}\text { Coconut } \\ \operatorname{diet}(A L C)\end{gathered}$$\quad S E \quad S^{a}(\%)$

\begin{tabular}{|c|c|c|c|c|c|}
\hline No of lambs & & 62 & & 62 & \\
\hline Live-weight at start (Wto, $\mathrm{kg}$ ) & & 11.9 & 0.17 & 12.0 & 0.17 \\
\hline Age at start $(A g o, d)$ & & 28 & 1.4 & 30 & 1.3 \\
\hline Littermate at birth $(B \mid)$; relative frequency $(\%)$ & $B 11$ & 27.6 & 0.4 & 23.6 & \\
\hline & $B / 2$ & 67.3 & & 67.3 & \\
\hline & $B / 3$ & 5.1 & & 9.1 & \\
\hline
\end{tabular}

Rearing parameters during investigated fattening stages

\begin{tabular}{lccccc} 
ADG 0-20 d (g/d) b & 115 & 9.8 & 188 & 11.7 & $* \star \star$ \\
ADG 20-40 d & 340 & 10.8 & 328 & 10.9 & $\mathrm{NS}$ \\
ADG 40-60 d & 339 & 22.8 & 341 & 10.4 & $\mathrm{NS}$ \\
ADG 60-Se & 383 & 12.6 & 381 & 9.4 & $\mathrm{NS}$ \\
ADG 0-SI & 307 & 5.3 & 320 & 4.9 & $(9 \%)$ \\
ADG 20-SI & 357 & 6.5 & 355 & 6.4 & $\mathrm{NS}$ \\
Live-weight at slaughter (WtSI, kg) & 40.5 & 0.1 & 40.6 & 0.1 & $\mathrm{NS}$ \\
Duration of fattening (Dufat, d) & 94.3 & 1.5 & 90.6 & 1.5 & $(11 \%)$ \\
& & & & & \\
Carcass parameters & & & & & \\
Carcass weight (Wtcar, kg) & 19.9 & 0.11 & 20.0 & 0.11 & $\mathrm{NS}$ \\
Kill-out percentage (KO\%) & 51.8 & 0.20 & 52.0 & 0.20 & $\mathrm{NS}$ \\
Nconf (conformation, EUROPA) & 2.4 & 0.10 & 2.4 & 0.10 & $\mathrm{NS}$ \\
NFext (external fat, EUROPA) & 2.3 & 0.08 & 2.6 & 0.08 & $(6 \%)$ \\
DFdo (depth of dorsal fat, mm) & 2.4 & 0.23 & 2.6 & 0.20 & $\mathrm{NS}$ \\
NFro (perinephric fat, g) & 215 & 16.0 & 197 & 12.0 & $\mathrm{NS}$ \\
NFrib (inter-rib fat, 1-5) & 2.9 & 0.08 & 3.0 & 0.07 & $\mathrm{NS}$ \\
NFirm (firmness, 1-4) & 2.40 & 0.09 & 2.35 & 0.09 & $\mathrm{NS}$ \\
& & & & & \\
\hline
\end{tabular}

a $S$ : significant levels of Fisher-Snedecor's $F$ test for: ${ }^{*} P<0.05 ;{ }^{* *} P<0.01 ;{ }^{* *} P<0.001$; NS: non significant; $(P>$ $0.20)$; ${ }^{\mathrm{b}} A D G 0-20 \mathrm{~d}$ : average daily gain between 0 and $20 \mathrm{~d}$ of fattening.

$P<0.01$ ) but there was no effect of starting weight (table $V$ ). The second stage (20-60 d) indicated essentially that heavy lambs at the start exhibited the highest growth (357 g vs $302 \mathrm{~g} ; P<0.01$ ) without diet effect. During the 40-60-d period no significant difference was noted; only the lightest weaning lambs tended to show a higher compensatory growth than the heavy lambs ( $A D G_{40-60 d:}: 359 \mathrm{~g}$ vs $\left.333 \mathrm{~g}\right)$. During the last period (60 d-SI), the lambs fed on the ALc diet tended to maintain a higher growth rate $\left(A D G_{60-s)}: 400 \mathrm{~g}\right.$ vs 370 g; $P<0.05)$. Overall, during the fattening period ( $0 \mathrm{~d}-S /$ ), starting with ALc provided the best daily growth (322 g vs $305 \mathrm{~g}$; $P<$ 0.05). Similarly, the fattening duration of the same group was shorter ( $89 \mathrm{~d}$ vs $91 \mathrm{~d}$; $P<0.05)$. The same could be seen for heavy lambs at weaning ( $86 \mathrm{~d}$ vs $95 \mathrm{~d} ; P<$ $0.001)$, without influence of the crossfactors. 
Table IV. Growth patterns: comparison between polynomial regression coefficients fitted on fattening time and according to the diets for the individual lamb's $A D G\left(y=a 0+a 1 t+a 2 t^{2}+a 3 t^{3}\right)$. Levels of significance of $F^{\mathrm{a}}$.

\begin{tabular}{|c|c|c|c|c|c|c|c|}
\hline & $\begin{array}{l}\text { No of } \\
\text { lambs }\end{array}$ & $\mathrm{a} 0$ & a 1 & $\mathrm{a} 2$ & a3 & $A D G_{\max }{ }^{b}$ & Dufat $_{\max }{ }^{\mathrm{c}}$ \\
\hline \multicolumn{8}{|l|}{ Standardized sample } \\
\hline Diets (Alr, ALc) & 62 & $* \star *$ & $*$ & * & * & NS & NS \\
\hline \multicolumn{8}{|l|}{ Sample of marginal lambs } \\
\hline Diets (ALr, ALc) & 34 & ** & * & $11 \%$ & NS & NS & NS \\
\hline Wto (heavy, light) & 34 & * & ${ }^{* *}$ & $\star \star *$ & $\star \star \star *$ & $11 \%$ & $\star \star$ \\
\hline Cross factors (Diets $\times$ Wto) & 17 & NS & NS & NS & NS & NS & NS \\
\hline
\end{tabular}

a Level of significance for: " $P<0.05 ;{ }^{* *} P<0.01 ;{ }^{* * *} P<0.001$; NS: non significant for $P<0.20$; ${ }^{\mathrm{D}} A D G_{\max }$ : maximum average daily gain; ${ }^{C}$ Dufat $t_{\text {max }}:$ time of fattening in respect to $A D G_{\max }$.

The pattern of growth curves displays a smoother design as light lambs were fed on ALC at the start (table IV; fig 2). Diet effect was obvious at the beginning of fattening $\left(a_{0}\right.$ and $\left.a_{2}, P<0.01\right)$. The effect of lamb weight was also clearly indicated and it more significantly affected the end of the growth curve. The ADG maxima did not differ, but the corresponding fattening days indicated that the heavy lambs at the start were those maturing earlier (Dufat $t_{\text {max }}$ : 62 d vs $83 \mathrm{~d} ; P<0.01$ ).

\section{Food conversion ratios}

Alimentary efficiency of ALc diet was improved during the post-weaning period $(0-$ $20 \mathrm{~d})$ in comparison with the reference diet $(F C R=2.42$ vs $3.18 ; P<0.01$; table VI $)$. Meanwhile, fattening with the same foodstuff during the $20 \mathrm{~d}$-slaughter period yielded a reversal of alimentary efficiency $(F C R=3.61$ for ALC vs 3.35 for ALr; $P<$ $0.05)$.

The pattern moved from non significant differences (throughout 20-40 d and 40-
$60 \mathrm{~d}$ period between both diets) to significant deterioration in ALC during the last fattening stage $\left(F C R_{60-S I}=3.9\right.$ vs 3.56 for ALr; $P<0.05)$. During the entire fattening period, alimentary efficiency in the 2 diets was almost similar and FCR reached 3.35 $\mathrm{kg}$ ingested $D M$ foodstuff/ $\mathrm{kg}$ average live weight gain. In the ALC diet, food conversion ratios progressively increased throughout the periods until they became stable; this contrasted with the ALr diet in which $F C R$ development was discontinuous. However, a sharp increase in FCR occurred during the 40-60-d period in both diets $(+1$ and +1.25 for ALC and ALr respectively). The decline in the alimentary efficiency occurred when the respective live weights were $26 \mathrm{~kg}$ (ALC) and $24 \mathrm{~kg}$ (ALr) for the middle period (50 d).

\section{Volatile fatty acids in the rumen fluid}

With sampled rumen fluid, fattening time had a significant effect. Over time, propionic acid concentration decreased evenly while acetic acid concentration increased. Meanwhile, the final level of propionic acid 


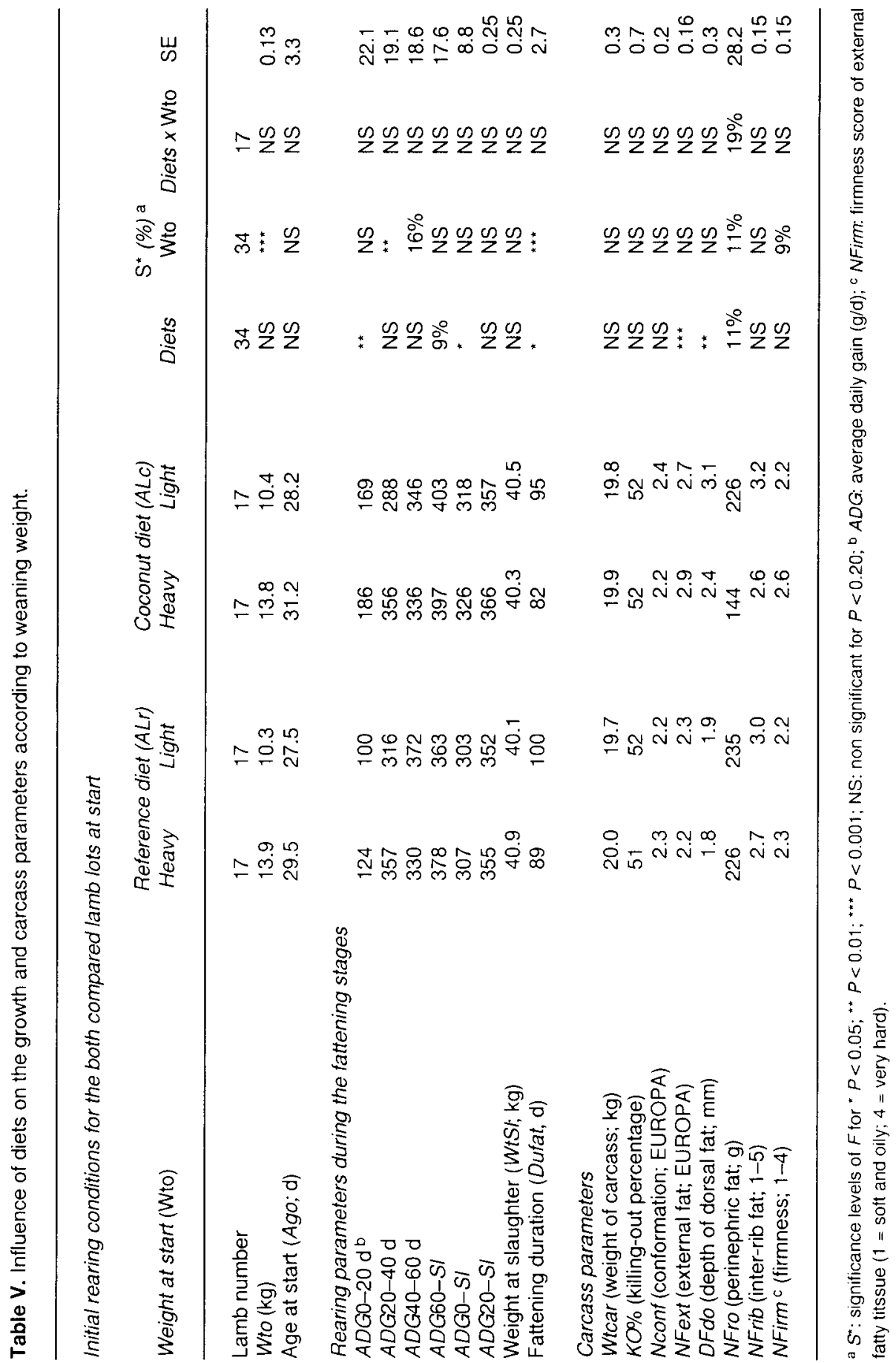



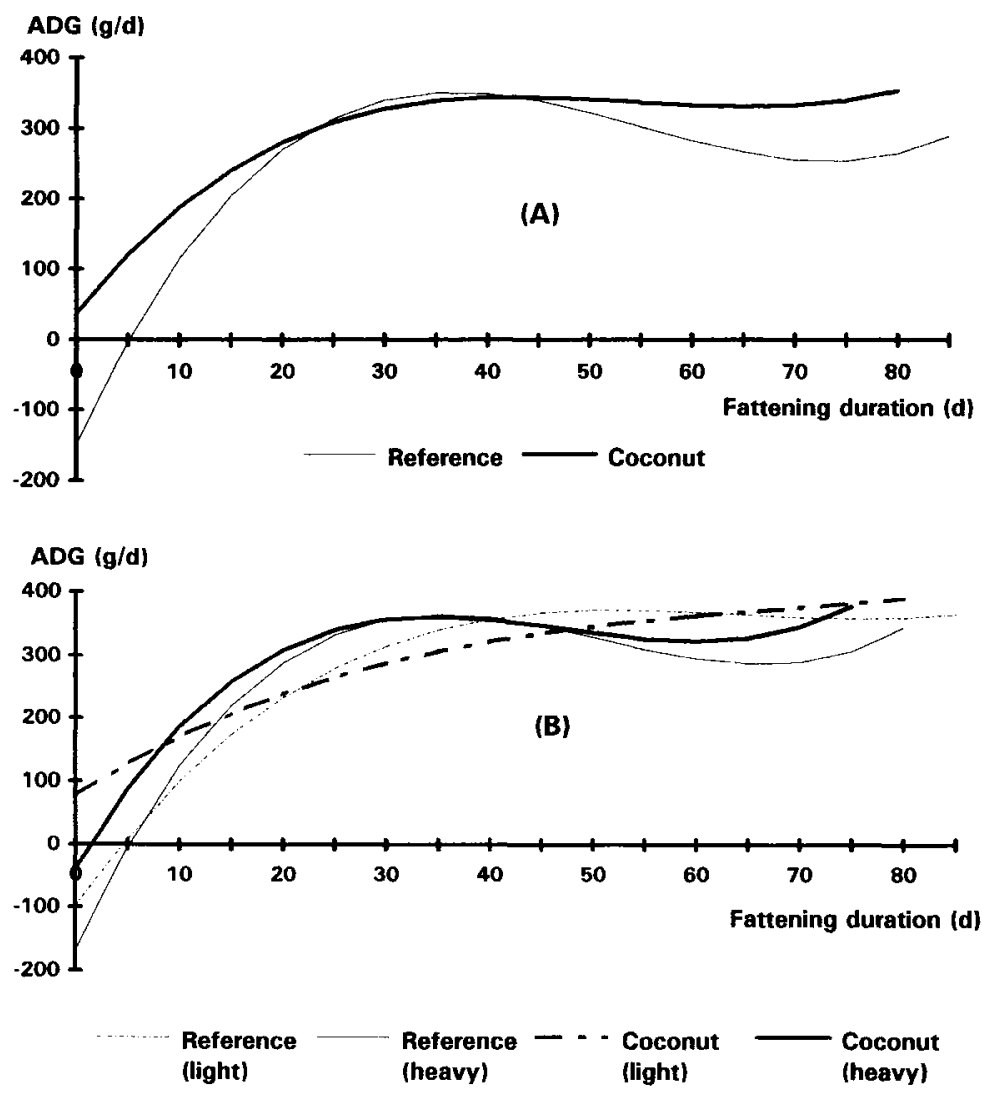

Fig 2. Evolution of average daily gain ( $A D G, \mathrm{~g} / \mathrm{d}$ ) with the polynomial adjustment fitted on the fattening duration according to the experimental diets (reference, coconut). A. Standardized samples (2 $\times(n=62)$. B. Samples of marginal lambs, light or heavy weight at weaning $(4 \times(n=17)$.

remained high $(34 \%)$. ALc diet tended to induce a slight increase in isovaleric acid $(P<0.07)$ during the second stage of fattening. Neither diet factor differed, nor was the cross-effect consistent (table VII).

With Rusitec incubators, VFA pattern differed between the 2 starter diets during the first period (fig 3). The propionic acid proportion declined regularly down to $25 \%$ while the acetic acid percentage remained stable $(37 \%)$ for the ALc diet. Taking the reference diet ( $A L r$ ), both $\mathrm{C}_{2}$ and $\mathrm{C}_{3}$ acids decreased at the same ratio over the starter period. Correlatively, the other VFA displayed an increasing pattern in both diets. Meanwhile, butyric acid and particularly caproic acid levels were lower in ALr than in ALc. After transition and with the same finishing-fattening feed, the various acid proportions in the incubators became more stable. However, when $\mathrm{C}_{3}$ and $\mathrm{C}_{4}$ levels were similar in $A L C$, the $C_{3}$ proportion was 
Table VI. Diet effect on food conversion ratio (FCR) throughout fattening stages.

\begin{tabular}{|c|c|c|c|c|c|}
\hline $\begin{array}{l}\text { Food conversion } \\
\text { ratios }\end{array}$ & $\begin{array}{l}\text { Reference } \\
\operatorname{diet}(\text { Alr) }\end{array}$ & SE & $\begin{array}{r}\text { Coconut } \\
\operatorname{diet}(A L C)\end{array}$ & $S^{d}$ & $\mathrm{~S}^{*}(\%)^{\mathrm{a}}$ \\
\hline$F C R^{\mathrm{b}} 0-20 \mathrm{~d}$ & 3.18 & 0.24 & 2.42 & 0.07 & $*$ \\
\hline FCR 20-40d & 2.54 & 0.22 & 2.92 & 0.09 & $12 \%$ \\
\hline FCR 40-60d & 3.79 & 0.34 & 3.92 & 0.12 & NS \\
\hline FCR $60-S I$ & 3.56 & 0.15 & 3.91 & 0.05 & $*$ \\
\hline$F C R 0-S I$ & 3.28 & 0.07 & 3.42 & 0.04 & $11 \%$ \\
\hline FCR 20-SI & 3.35 & 0.09 & 3.61 & 0.06 & * \\
\hline$b(0-S /)^{c}$ & 1.52 & 0.24 & 1.56 & 0.13 & NS \\
\hline
\end{tabular}

a $S^{*}$ : significant levels of Student's $t{ }^{*} P<0.05 ;{ }^{* *} P<0.01 ; \mathrm{NS}$ : non significant; $P>0.20 ;{ }^{\mathrm{b}}$ FCR: $\mathrm{kg}$ ingested $\mathrm{DM} / \mathrm{kg}$ gain of live-weight; ${ }^{c} b$ : allometric coefficient on the entire fattening period; ${ }^{d} S E$ : standard error of mean estimated by computation.

Table VII. Patterns of the fluid volatile fatty acids (VFA, molar \%) in the rumen according to the diets and to the fattening duration (DuFat, $n=6$ ).

\begin{tabular}{|c|c|c|c|c|c|c|c|c|c|c|}
\hline \multirow{2}{*}{$\begin{array}{l}\text { Diets } \\
\text { Dufat }\end{array}$} & \multicolumn{3}{|c|}{ Reference diet $(A L r)$} & \multicolumn{3}{|c|}{ Coconut diet (ALC) } & \multirow[b]{2}{*}{ SE b } & \multirow[b]{2}{*}{ Stage } & \multirow{2}{*}{$\begin{array}{l}\mathrm{F} \text { a } \\
S \times D\end{array}$} & \multirow[b]{2}{*}{ Diets } \\
\hline & $20 d$ & $50 d$ & Slaughter & $20 d$ & $50 d$ & Slaughter & & & & \\
\hline VFA (\%) & 39.9 & 46.1 & 51.0 & 40.6 & 47.3 & 47.3 & 1.6 & $* * *$ & NS & NS \\
\hline Propionic & 44.4 & 42.7 & 34.2 & 42.6 & 39.4 & 33.9 & 2.1 & $* * *$ & NS & NS \\
\hline Isobutyric & 0.2 & 1.3 & 1.2 & 0.3 & 0.4 & 1.7 & 0.3 & $\star \star \star$ & NS & NS \\
\hline Butyric & 11.1 & 6.7 & 8.0 & 11.7 & 8.4 & 10.0 & 1.5 & ** & NS & $(19 \%)$ \\
\hline Isovaleric & 0.3 & 0.2 & 1.8 & 0.4 & 0.3 & 2.7 & 0.2 & *** & NS & $(7 \%)$ \\
\hline Valeric & 3.7 & 2.6 & 3.4 & 4.2 & 3.4 & 3.8 & 0.6 & $(18 \%)$ & NS & NS \\
\hline Caproic & 0.4 & 0.4 & 0.3 & 0.2 & 0.7 & 0.5 & 0.3 & $(6 \%)$ & NS & NS \\
\hline
\end{tabular}

a $F$ : significant levels of Fisher-Snedecor's $F$ for: ${ }^{* *} P<0.001 ;{ }^{* *} P<0.01$; ${ }^{*} P<0.05$; NS: non significant for $P<$ 0.20 ; from the variance analysis carried out on the transformed data: $\arcsin \sqrt{ }{ }^{b}{ }^{b} S E$ : standard error of the mean.

prevalent in ALr. The proportion of $\mathrm{C}_{6}$ acid in the 2 diets increased steadily.

\section{Carcass parameters}

\section{Standardized sample of lambs at start}

The differences in carcass parameters failed to reach a level of significance (table
III). A slight increase in external fattening was to be seen in ALc (NFext $=2.6$ vs 2.3; $P<0.07$ ). Likewise, the distribution pattern of the external fat layer qualities (firmness and colour) was not significant in the overall pattern comparison (table VIII). However, the percentage of light-coloured carcasses increased with ALC (Ncoul 2: $35.5 \%$ vs $25.8 \%$ for $A L r$ ) with the reverse observed for the light-bistre carcasses 

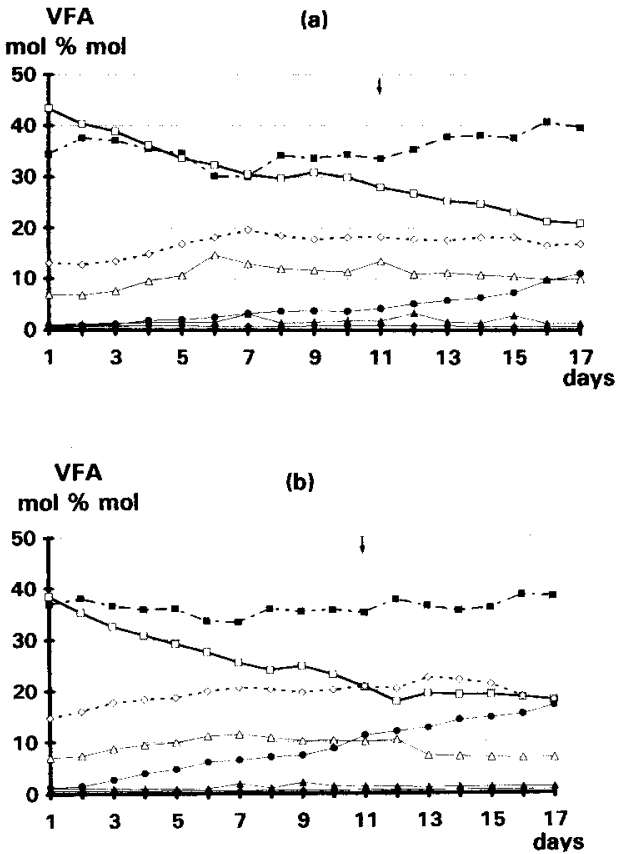

Fig 3. Fermentary pattern of volatile fatty acids (\%mol) during the transition period between starter and fattening diets (Rusitec). a. Reference starter diet ( $A L r)$ for $11 \mathrm{~d}$ then fattening diet. b. Coconut-oil starter diet (ALC) for $11 \mathrm{~d}$ then fattening diet. - $-\mathrm{C} 2$; $-\mathrm{C} 3$; $-\longrightarrow$ iC4; - 4 - 4 ; - $-\mathrm{iC} 5 ;-\Delta-\mathrm{C} 5 ;-\longrightarrow \mathrm{C} 6$.
(Ncoul 4: 21\% vs 30.6\%). However, probably due to the small size of the sample, the diferences were not significant. In the lambs overall, the proportion of very firm carcasses was poor (Nfirm 4: 3.2\%); $38 \%$ of white carcasses conformed to the commercial requirements; $20 \%$ were reddishbrown; 26\% were light bistre; and $16 \%$ were light yellow-coloured.

\section{Sample of marginal lambs}

In this sample, main diet effect was significant for the external fat development score. Coconut diet produced fatter carcasses 2 months later (NFext $=2.8$ vs 2.3, $P<0.001 ; N F d o=2.7 \mathrm{~mm}$ vs $1.9 \mathrm{~mm} ; P<$ 0.01 ; table $V)$. However, internal fattening tended to show a minor increase (NFro $=$ $185 \mathrm{~g}$ vs $231 \mathrm{~g}$ in ALr; $P<0.11$ ).

The same pattern was relevant only for heavy lambs in comparison with light animals for perinephric fat, notably for the coconut lot (NFro $=144 \mathrm{~g}$ vs $226 \mathrm{~g}$ for light lambs). Finally, the firmness score tended to be higher for heavy lambs especially when fed on ALc (NFirm = 2.6 for ALC heavy vs 2.2 for ALc light; $P<0.08$ ).

Table VII. Patterns of the fluid volatile fatty acids (VFA, molar \%) in the rumen according to the diets and to the fattening duration (DuFat, $n=6$ ).

\begin{tabular}{|c|c|c|c|c|c|c|c|c|c|c|}
\hline \multirow{2}{*}{$\begin{array}{l}\text { Diets } \\
\text { Dufat }\end{array}$} & \multicolumn{3}{|c|}{ Reference diet $(A L r)$} & \multicolumn{3}{|c|}{ Coconut diet $(A L C)$} & \multirow[b]{2}{*}{ SE b } & \multicolumn{3}{|c|}{$\mathrm{F} \mathrm{a}$} \\
\hline & $20 d$ & $50 d$ & Slaughter & $20 d$ & $50 d$ & Slaughter & & Stage & $S \times D$ & Diets \\
\hline VFA (\%) & 39.9 & 46.1 & 51.0 & 40.6 & 47.3 & 47.3 & 1.6 & $\star \star \star \star$ & NS & NS \\
\hline Isobutyric & 0.2 & 1.3 & 1.2 & 0.3 & 0.4 & 1.7 & 0.3 & $* *$ & NS & NS \\
\hline Butyric & 11.1 & 6.7 & 8.0 & 11.7 & 8.4 & 10.0 & 1.5 & $* \star$ & NS & $(19 \%)$ \\
\hline Isovaleric & 0.3 & 0.2 & 1.8 & 0.4 & 0.3 & 2.7 & 0.2 & $* \star * *$ & NS & $(7 \%)$ \\
\hline Valeric & 3.7 & 2.6 & 3.4 & 4.2 & 3.4 & 3.8 & 0.6 & $(18 \%)$ & NS & NS \\
\hline Caproic & 0.4 & 0.4 & 0.3 & 0.2 & 0.7 & 0.5 & 0.3 & $(6 \%)$ & NS & NS \\
\hline
\end{tabular}

a $F$ : significant levels of Fisher-Snedecor's $F$ for: ${ }^{* * *} P<0.001 ;{ }^{* *} P<0.01 ; " P<0.05$; NS: non significant for $P<$ 0.20 ; from the variance analysis carried out on the transformed data: arcsin $x .{ }^{b} S E$ : standard error of the mean. 
Table VIII. Influence of fattening diet upon the subcutaneous fatty tissue quality (firmness and colour); frequency patterns of standardized sample $(n=2 \times 62)$.

\begin{tabular}{|c|c|c|c|c|c|c|c|}
\hline NFirm a & 1 & 2 & 3 & 4 & & & \\
\hline \multicolumn{8}{|l|}{ Diets } \\
\hline Reference (ALr) & 8.0 & 46.8 & 41.9 & 3.2 & & & \\
\hline Coconut (ALC) & 12.9 & 41.9 & 41.9 & 3.2 & & & \\
\hline Overall & 10.5 & 44.4 & 41.9 & 3.2 & & & \\
\hline NCoul b & 1 & 2 & 3 & 4 & 5 & 6 & 7 \\
\hline \multicolumn{8}{|l|}{ Diets } \\
\hline Reference (ALr) & 8.0 & 25.8 & 17.7 & 30.6 & 1.6 & 9.7 & 6.5 \\
\hline Coconut (ALC) & 6.5 & 35.5 & 16.1 & 21.0 & 4.8 & 8.1 & 8.1 \\
\hline Overall & 7.3 & 30.6 & 16.9 & 25.8 & 3.2 & 8.9 & 7.3 \\
\hline
\end{tabular}

a NFirm: 1 = soft and oily; 4 = very hard; $\chi^{2}=0.86 ; P(\alpha)=84 \% ;{ }^{b}$ NCoul : 1 = white, $2=$ creamy white, $3=$ light reddish brown, $4=$ light bistre, $5=$ brown reddish, $6=$ light yellow, $7=$ light bistre with greenish reflection; $\chi^{2}=3.43 ; P$ $(\alpha)=76 \%$.

The small number of lambs in the subclass $(n=17)$ was insufficient to compare the pattern of frequencies for external fat carcass colours.

\section{DISCUSSION}

\section{Growth}

Supplying $5 \%$ coconut oil in the starter diet (78\% total fatty matter) offered to earlyweaned male lambs reduced the difficulties encountered at the transition stage. These lambs reared in winter and fed on ALc showed an improved growth rate during the post-weaning period (+ $63 \%$ (table III) and $+58 \%$ (table V) for standardized and marginal samples). There may also be a reduction in loss of weight according to the $A D G$ levels which were independent of live weight at the start (weaning weight factor, heavy or light, was not within the limits of significance; table V). The stress adaptive period induced negative growth in the immediate post-weaning stage (Thériez,
1985; Lane and Albrecht, 1991). The same effect was observed ( $+9 \%$ and $+35 \%$ ), but was irregular according to the weight class of lambs at weaning when they were reared in summer (Bozzolo et al, 1991). This difference was more pronounced for the light lamb class in the summer trial ( $+233 \%$ vs $+69 \%$ in winter) but not for the heavy animals $(-13 \%$ in summer vs $+50 \%$ in winter). A possible explanation is that the medium-chain fatty acids in the diet (37\% total FA constituents or $2.2 \%$ DM, essentially in lauric acid form) are used as a high-energy fuel. Moreover, they may improve the amino acid balance as reported by several authors for monogastric animals (Benevenga et al, 1989; Cera et al, 1989; Mahan, 1991) and for preruminant lambs (Aurousseau et al, 1989). This small difference regarding the summer trial can be attributed to the specific season effect. This hypothesis can explain the higher energy demand for both lamb categories (light and heavy) reared in winter and confronted with cold. They were therefore more sensitive to the high efficiency of the medium-chain fatty acids. The best food 
conversion ratio obtained with coconut oil $(-24 \%)$ with a major alimentary fat content $(+52 \%)$ could strengthen this suggestion. This advantage ensured an easier transition period. Finally, the delayed effect of the coconut oil-starter diet induced more regularity in the growth pattern than the reference diet (fig 2). This was corroborated during the initial feeding period with lambs fattened in summer. In the present trial, post-20 d growth showed no difference. Therefore, the compensatory growth did not allow the reference lamb group to overcome the handicap accumulated during the transition period. At least, the coconut starter reduced fattening time by $4 \mathrm{~d}$. This further increased to $7 \mathrm{~d}$ in lambs weighing $<11 \mathrm{~kg}$ at the beginning of the trial.

\section{Pattern of ruminal fermentation}

Regarding fermentation in the rumen, the development of volatile fatty acid patterns within the fattening period attained more normal proportions: the propionic acid level decreased from $43 \%$ to $34 \%$. This trend could be associated with straw intake which increases with age and could produce better insalivation and a longer fermentation time. However, the percentage remained high in comparison with the published data (Ørskov et al, 1975; Murphy and L'Estrange, 1977). On the contrary, the butyric acid percentage was low $(\mathrm{C} 4<$ $10 \%)$. These values agree with the findings of Sutton et al (1983), which were based on non-protected coconut oil introduced into the rumen. The development of the volatile fatty acids in the Rusitec incubators as the diet changes mainly displayed a difference between in vitro and in vivo data. On the one hand, the caproic acid proportion in both semi-continuous incubators arose, probably due to its own parameters (flow, artificial saliva quality, in- ert walls). On the other hand, the trends were similar when the relative values of in vivo (between $20 \mathrm{~d}$ and $50 \mathrm{~d}$ ) and in vitro Rusitec data on the starter diets were observed. The presence of coconut oil induced a faster decrease in propionic acid percentage, maintenance of the acetate proportion and an increase in butyrate level. These tendencies were inconsistent with Sutton's findings (1983). It is suggested that a possible cross-reaction with the premix antibiotics (oxytetracyclin and lasalocid) included in both the starter diets could be a possible explanation.

\section{CARCASS QUALITIES}

Carcass characteristics did not differ except for the slight increase in external fattening for lambs in the coconut oil group. In particular, the firmness and colour of carcasses did not deviate significantly from the reference. This is in contrast with the trend observed in the summer lamb trial and the observations reported by Aurousseau et al (1973) where coconut oil induced firmer and whiter carcasses. Nevertheless, we observed the same tendency with the heavy lamb class in the marginal sample (NFirm: 2.6 vs 2.3; $P<0.09$ ). Overall, firmness in the winter trial was reduced, notably for the coconut diet (very firm grade: $3.2 \%$ vs $47.2 \%$ in summer trial for ALc and $3.2 \%$ vs $16.7 \%$ for ALr). Similarly, whiter carcasses were numerically more significant in the entire summer trial (NCoul 1-2: $60.7 \%$ vs $37.9 \%$ in winter). The hypothesis of a lowering of the basal metabolism with heat is assumed (Beede and Collier, 1986). Then the cortisol/ progesterone balance could interfere with insulin implication in lipogenesis. In chronic thermal heat stress, the lower concentration of cortisol and inversely the higher level of progesterone induce insulin resistance in the peripheral tissues (Guesnet and De- 
marne, 1987) and possibly a limitation in adipocyte desaturase activity. Moreover, the contribution of exogenous fatty acids, which are mostly saturated in ruminants, is enhanced in lipogenesis. On the contrary, with cold, increased cortisol and thyroxin levels increase the turnover of subcutaneous fatty tissue. Endogenous lipogenesis could then result (in Christie, 1981), with a higher desaturase activity (Wahle, 1974).

In this experiment, it should be also recalled that the amounts of starter feed offered were lighter than in the summer trial $(12 \mathrm{~kg} v s 17 \mathrm{~kg}$ ). Therefore, the proportion of the starter diet of the total feed intake (only 13\%) did not provide a large contribution to the deposition of fat in the subcutaneous tissue.

Besides, in the lambs fed on this diet, fat deposition was low on account of their young age ( $<50 \mathrm{~d}$ on average). In heavy lambs, a slight increase in external fattening and a slight decrease in perinephric fat with ALC diet was noted. The regularity of the growth curve and possible hormonedependent events probably influenced this data. These factors are able to accelerate precocity of heavy lambs. Thériez et al (1973) reported the same observation. The significant increase in feed conversion ratio (+1) during the $40-60 \mathrm{~d}$ fattening growth stage, when lambs average $30 \%$ of their live weight at maturity possibly indicates full development of the polygastric function. Accordingly, the alimentary efficiency of the supplied coconut oil starter diet could be used over a longer time than selected in the present study trial (21 d) and could be extended for up to $35 \mathrm{~d}$ after weaning.

\section{ACKNOWLEDGMENT}

This study was supported by the Conseil Régional de Midi-Pyrénées to encourage applied scientific research.

\section{REFERENCES}

Allen OB, Burton JH, Holt JD (1983) Analysis of repeated measurements from animal experiments using a polynomial regression. $J$ Anim Sci 57, 765-770

Andrews RP, Ørskov ER (1970) The nutrition of the early weaned lamb: II. The effect of dietary protein concentration, feeding level and sex on body composition at two live-weights. J Agric Sci (Camb) 75, 19-26

Aurousseau B, Thériez M, Daniel M (1973) Influence de la nature des matières grasses incorporées dans l'aliment d'allaitement sur le métabolisme lipidique de l'agneau de bergerie. Ann Biol Anim Biochim Biophys 13, 93-105

Aurousseau $B$, Vermorel $M$, Thériez $M$, Vezinhet A (1989) Effects of substitution of tricaprylin or coconut oil for tallow in milk replacers offered to preruminant lambs. Ann Zootech 38, 49-59

Beede DK, Collier RJ (1986) Potential nutritional strategies for intensively managed cattle during thermal stress. J Anim Sci62, 543-554

Benevenga NJ, Steinman-Goldsworthy JK, Crenshaw TD, Odle J (1989) Utilization of medium-chain triglycerides by neonatal piglets: I. Effects on milk consumption and body fuel utilization. J Anim Sci 67, 331-339

Bénévent $M$ (1971) Croissance relative pondérale post-natale, dans les deux sexes, des principaux tissus et organes de l'agneau Mérinos d'Arles. Ann Biol Anim Biochim Biophys 11, 5-39

Blanchart G, Durand M, Barry JL, BouillierOudot M, Jouany JP (1989) Intérêts et limites des fermenteurs à flux semi-continu de type Rusitec dans l'étude des fermentations du rumen. Ann Zootech 38, 285-314

Bouillier-Oudot M, Bozzolo G, Phrem G, Grasset $D$, Manse $H$ (1982) Optimisation du jugement de la fermeté du gras de couverture des carcasses d'agneaux de bergerie. Ann Zootech 41, 187-203

Bozzolo G, Bouillier-Oudot M, De Boisseson E, Ghassan M, Grasset D (1990) Influence des performances zootechniques sur les caractéristiques des tissus adipeux d'agneaux de bergerie, sevrés précocement et alimentés avec un régime à forte concentration énergétique. Ann Zootech 39, 77-94 
Bozzolo G, Bouillier-Oudot M, Aoun M, Grasset $D$, Manse $H$ (1991) Influence des acides gras alimentaires à chaîne moyenne, incorporés dans le régime de transition en postsevrage, sur les caractéristiques de croissance et de carcasse d'agneaux sevrés précocement et engraissés intensivement en bergerie en été. Ann Zootech 40, 85-105

Bozzolo G, Bouiller-Oudot M, Quenardelle P, Grasset D, Manse H (1992) Influence de l'incorporation de saindoux dans l'aliment concentré sur la croissance et les qualités de carcasse chez l'agneau mâle sevré précocement. Ann Zootech 41, 205-221

Busboom JR, Miller GJ, Field RA, Grouse JD, Riley ML, Nelms GE, Ferrell CL (1981) Characteristics of fat from heavy ram and wether lambs. J Anim Sci 52, 83-92

Cera KR, Mahan DC, Reinhart CA (1989) Apparent fat digestibilities and performances responses of postweaning swine fed diets supplemented with coconut oil, corn oil or tallow. $J$ Anim Sci67, 2040-2047

Christie WW (1981) The effects of diet and other factors on the lipid composition of ruminant tissues and milk. In: Lipid Metabolism in Ruminant Animals (Christie WW, ed) Pergamon Press, Oxford, 193-225

Crouse JD, Field RA, Chant JL, Ferrell CL, Smith GM, Harrison VL (1978) Effect of dietary energy intake on carcass composition and palatability of different weight carcasses from ewe and ram lambs. J Anim Sci 47, 1207-1218

Czerkawski JW, Brekenridge G (1977) Design and development of a long-term rumen simulation technique (Rusitec). Br J Nutr 38, 371384

Ferrell CL, Koong LJ, Nienaber JA (1986) Effect of previous nutrition on body composition and maintenance energy costs of growing lambs. Br J Nutr 56, 595-605

Folch J, Lees M, Sloane Stanley GH (1957) A simple method for the isolation and purification of total lipids from animal tissues. $J$ Biol Chem 226, 497-509

Frost SC, Wells MA (1981) A comparison of the utilization of medium and long chain fatty acids for oxidation and ketogenesis in the suckling rat: in vivo and in vitro studies. Arch Biochem Biophys 211, 357
Garton GA, Howell FDD, Duncan WRH (1972) Influence of dietary volatile fatty acids on the fatty acid composition of lamb triglycerides with special reference to the effect of propionate on the presence of branched chain components. Br J Nutr 28, 409-416

Giger-Reverdin S, Aufrère J, Sauvant D, Demarquilly C, Vermorel M, Pochet S (1990) Prévision de la valeur énergétique des aliments composés pour les ruminants. INRA Prod Anim 3, 181-188

Guesnet P, Demarne $Y$ (1987) Les hormones stéroïdes: corticostéroïdes, progestérone, œstrogènes et androgènes. In: La Régulation de la Lipogenèse et la Lipolyse Chez les Mammifères. INRA, Paris, 67-83

Jensen C, Buist NRM, Wilson T (1986) Absorption of individual fatty acids from long chain or medium chain tryglycerides in very small infants. Am J Clin Nutr 43; 748-751

JOCE $(1971,1972,1973)$ Méthodes d'Analyse des Aliments pour les Animaux. Journal Officiel de la Communauté Européenne

Jouany JP (1982) Volatile fatty acid and alcohol determination in digestive contents silage juices, bacterial cultures and anaerobic fermentor contents. Sci Alim 2, 131-144

Lane SF, Albrecht KA (1991) Growth and plasma metabolites of lambs weaned to legume pasture at 28 days of age. J Anim Sci 1, 305-317

Leat WMF, Harrison PA (1975) Digestion, absorption and transport of lipids in the sheep. In: Digestion and Metabolism of the Ruminant (McDonald IW, Warmer $\mathrm{ACl}$, eds) CSIRO, Sydney, Australia, 481-195

Mahan DC (1991) Efficacy of initial postweaning diet and supplemental coconut oil or soybean oil for weanling swine. J Anim Sci 69, 13971402

Molénat G, Thériez M (1973) Influence du mode d'élevage sur la qualité de la carcasse de l'agneau de bergerie. Ann Zootech 22, 279293

Murphy J, L'Estrange JL (1977) The performance and carcass fat characteristics of lambs fattened on concentrate diets: 1 . Effect of maize and barley as the cereal source and of dietary supplementation with roughage, vitamin $E$, cobalt and vitamin $B_{12}$. Ir J Agric Res 16, 187-204 
Ørskov ER, Duncan WR, Carnie CA (1975) Cereal processing and food utilization by sheep. III. Effect of replacement whole barley by whole oats on food utilization and firmness and composition of subcutaneous fat. Anim Prod 21, 51-59

Sutton JD, Knight R, Mc Allan AB, Smith RH (1983) Digestion and synthesis in the rumen of sheep given diets supplemented with free and protected oils. Br J Nutr 49, 419-432

Thériez M (1985) Engraissement et qualité des carcasses. Pâtre 329, 13-15
Thériez $M$, Molénat $G$, Daniel $M$, Aurousseau B (1973) L'allaitement artificiel des agneaux : III. Influence de la nature des graisses incorporées dans le lait de remplacement. Ann Zootech 22, 185-197

Turgeon OA, Brink DR, Bartle SJ, Klopfenstein TJ, Ferrell CL (1986) Effects of growth rate and compensatory growth on body composition in lambs. J Anim Sci 63, 770-780

Wahle KWJ (1974) Desaturation of long-chain fatty acids by tissue preparations of the sheep, rat and chicken. Comp Biochem Physiol 48B, 87-105 